\title{
EFFECTS OF ANATOMICAL CHARACTERISTICS AND WOOD DENSITY ON SURFACE ROUGHNESS AND THEIR RELATION TO SURFACE WETTABILITY OF HARDWOOD
}

\author{
Alia-Syahirah $\mathbf{Y}^{1}$, Paridah $\mathrm{MT}^{1,2, *}$, Hamdan $\mathbf{H}^{3}$, Anwar $\mathrm{UMK}^{3}$, Nordahlia $\mathrm{AS}^{3} \& \mathrm{Lee} \mathrm{SH}^{1}$ \\ ${ }^{1}$ Institute of Tropical Forestry and Forest Product, Universiti Putra Malaysia, 43400 UPM Serdang, Selangor, Malaysia \\ ${ }^{2}$ Faculty of Forestry, Universiti Putra Malaysia (UPM), 43400 UPM Serdang, Selangor, Malaysia \\ ${ }^{3}$ Forest Product Division, Forest Research Institute Malaysia, 52109 Kepong, Selangor, Malaysia \\ *parida@upm.edu.my
}

Submitted January 2019; accepted March 2019

\begin{abstract}
Adhesion capability of timbers varies greatly depending on anatomical structure and origin of the species. Unlike temperate hardwood, tropical hardwood has slightly different anatomical structure due to the influence of growing season. This study evaluates the anatomical structure of three tropical hardwood species of different densities, namely, batai, sesendok and kedondong and their effects on surface roughness and wettability. Rubberwood was used as control. The fibre length, wall thickness, lumen diameter, fibre diameter, vessel diameter, density, surface roughness and wettability were determined according to the relevant standards. The study showed that the strength of the relationship varied according to species and anatomical structure. Very good correlations $\left(\mathrm{r}^{2}>0.8\right)$ were obtained between the anatomical characteristics and density, surface roughness and surface wettability for batai, sesendok, kedondong and rubberwood. Rubberwood behaved differently than the three species while batai and sesendok were quite similar. Density and surface roughness were highly influenced by fibre wall and cell wall thicknesses while contact angle, by fibre length, fibre diameter, fibre wall thickness and lumen diameter. Surface wettability of the wood was influenced mainly by fibre wall thickness and surface roughness.
\end{abstract}

Keywords: Wood structure, contact angle, surface roughness, tropical hardwood

\section{INTRODUCTION}

Studies on wetting, i.e the interaction between adhesive liquid and wood, provide valuable information about adhesion properties of timber. Such information is essential in developing optimum adhesive system and efficient processing methods, as well as in predicting the bondstrength durability of glued wood products.

A good adhesive bonding in wood would produce the best quality of laminated and composite wood products. Adhesion properties such as wettability may influence the bonding of the end products (Amorim et al. 2013). Knowing and understanding the anatomical characteristics and physical properties of wood, including the surface roughness, will help in achieving good adhesive bonds (Shi \& Gardner 2001). Normally, wood with thicker fibre wall has higher density and this produces larger contact angle, and consequently, low wettability which is not good for adhesive bonding (Bao et al. 2016).
Wettability refers to the ability of the adhesive to make contact with the wood surface. Hence the ability of liquid adhesives to spread and penetrate wood cells depends very much on this property which would significantly affect the bonding strength between the two surfaces. There is a three-way interaction between anatomical structure, density and surface roughness of wood, and that these factors have direct influences on the surface wettability of the wood (Shi \& Gardner 2001). Adhesive penetration and contact angle were significantly influenced by adhesive viscosity and surface roughness (Cheng \& Sun 2012). When wood density increases, wettability and roughness significantly reduce (Amorim et al. 2013). The authors also concluded that between wood density and surface roughness, the former has greater influence on the surface wettability.

Since the anatomical structure of wood determines its wettability, the origin of the wood, 
climate and location are crucial factors to be considered. Surface wettability of tropical wood is higher than temperate wood due to the presence of diffuse-porous structure in the former compared with ring-porous structure in the latter (Agnieszka \& Pawel 2017). These diffuse-porous structures in hardwoods are known as vessels, a dominant feature in all hardwoods which are absent in softwoods.

Temperate hardwood of tropical origin have vessels for conducting sap upward. Vessels appear as holes or pores on a cross-section. The size, shape, and arrangement of pores vary considerably between species but are relatively constant within a species (Wiedenhoeft 2013). Vessel diameter of tropical hardwood is much larger than that of temperate hardwood. There are hundreds of tropical hardwoods species that can be converted into wood composites or laminated products. However, limited studies have been reported on the adhesion characteristics of these species. Thus, study on relationships between anatomical structure, wood density, surface roughness and wettability of tropical hardwoods is crucial particularly when using new wood species in application of the laminated product.

The purpose of this study was to evaluate the influence of anatomical characteristics, density and surface roughness on the surface wettability of three Malaysian tropical hardwood (batai, sesendok and kedondong). Rubberwood was used as control as it is the main species that is currently used in lamination and wood-based panel industries in South-East Asia region.

\section{MATERIALS AND METHOD}

\section{Preparation of samples}

Sawn timber of four different timber species, namely, batai (Paraserianthes falcataria), sesendok (Endospermum malaccensis), kedondong (Canarium sp.) and rubberwood (Hevea brasiliensis) were used in this study. Rubberwood was used as control as it possesses good adhesion properties and is widely used for furniture, wood working and wood-based panels. The lumbers were obtained from a local supplier. The wood lumbers were dried to moisture content of $12 \pm 3 \%$ and cut to $180 \mathrm{~mm} \times 127 \mathrm{~mm} \times 430 \mathrm{~mm}$ (thick $\times$ width $\times$ length) in size. The lumbers were further cut into various dimensions according to the types of tests to be conducted.
Chip thickness of the planer was $2.6 \mathrm{~mm}$ while the feed speed and cutting speed were in the range of 9 to $11 \mathrm{~m} \mathrm{~min}^{-1}$ and 30 to $40 \mathrm{~m} \mathrm{~s}^{-1}$ respectively.

\section{Determination of anatomical properties}

Each timber block of $10 \mathrm{~mm} \times 10 \mathrm{~mm} \times 15 \mathrm{~mm}$ in dimension was transversely, radially and tangentially sectioned for slide preparation following the method by Wheeler et al. (1989). The sample was then stained with safranin (1\%) for 5 to $10 \mathrm{~min}$. The stained sections were washed thrice using distilled water and dried with increasing concentrations of ethanol (50, 70 and $95 \%$ ). Clove oil was dropped onto the timber section which was then left to stand in the Petri dish for 5 min before the sample was placed on a glass slide with a cover slip on top. The permanent slides were put in an oven at $56{ }^{\circ} \mathrm{C}$ for $10 \mathrm{~min}$ and observed under the light microscope.

Timber tissue was macerated using method by Nordahlia (2009) to determine the fibre morphology. Samples were cut into matchstick sizes and boiled in a 2:1 acetic acid:hydrogen peroxide mixture at temperature $80{ }^{\circ} \mathrm{C}$ for 3 days, followed by washing three times using distilled water. Sections were stained with safranin for 2 hours. After staining, all the samples were dehydrated with an ethyl alcohol. Observations of the timber structure and quantitative measurement of fibre length and fibre wall thickness were carried out using light microscopy.

\section{Determination of wood density}

The density of wood samples was determined based on ASTM D2395-02 (ASTM 2002). The size of sample used was $100 \mathrm{~mm} \times 100 \mathrm{~mm} \times$ $100 \mathrm{~mm}$ with 40 replicates. The volume of air-dry wood was measured using digital vernier calipers in radial $(\mathrm{R})$, tangential $(\mathrm{T})$ and longitudinal (L) directions. The samples were oven dried at $103 \pm 2{ }^{\circ} \mathrm{C}$ until constant weight before determining their densities.

\section{Evaluation of surface roughness}

Immediately after planing, samples were cut into $4 \mathrm{~mm}$ thick $\times 20 \mathrm{~mm}$ width $\times 40 \mathrm{~mm}$ length for measurement of surface roughness 
using profilometer equiped with $0.75 \mathrm{mN}$ detector and $2 \mu \mathrm{m}$ stylus tip radius. The points of measurements were randomly marked on the surface of the test specimen. The surface roughness was measured with $4 \mathrm{~mm}$ evaluation length across the grain direction. Parameters measured were average roughness, root-meansquare deviation and maximum peak-to-valley height (ISO 4287, 1997). Average roughness is the distance from the profile to the average line over the length of the assessment while rootmean-square deviation is the square root of the average roughness of the square of the profile. Peak-to-valley height is the distance between peak and valley points of the profile which can be used as an indicator of the maximum defect height within the assessed profile. All measurements were taken from 10 replicates for each timber species. Roughness data was not filtered as machining effect was taken as a constant effect.

\section{Evaluation of surface wettability}

Surface wettability was determined based on contact angle between a droplet of liquid and wood surface. Measurement was conducted by using First Ten Angstroms FTA 1000 wettability tester using sessile-drop method. Seven specimens for each species with dimensions $4 \mathrm{~mm}$ thick $\times$ $20 \mathrm{~mm}$ width $\times 40 \mathrm{~mm}$ length were used for this test. Prior to the test, the specimens were conditioned at $20{ }^{\circ} \mathrm{C}$ and relative humidity $65 \pm 3 \%$ for 1 week until their moisture contents reached $10 \pm 2 \%$. Using a syringe tube, a droplet of water $(14 \mathrm{mg})$ was dropped onto the wood surface and the image was captured by a video camera after $2 \mathrm{~s}$ at $5 \mathrm{~min}$ intervals until the droplet of water was completely spread. The contact angles between the droplet and wood surface were automatically measured by the software analyser by assuming machining effect as constant.

\section{Statistical analysis}

Statistical analysis was carried out using SPSS programming software. Analysis of variance (ANOVA) was employed to analyse any differences in the properties studied. If the differences were significant, least significant difference test was used to determine which of the means were significantly different from one another. Regression and correlation analyses were carried out between wood anatomy properties and density, surface roughness and contact angle. Further correlations were carried out between density and surface roughness, and density and contact angle.

\section{RESULTS AND DISCUSSION}

\section{Anatomical characteristics}

Table 1 tabulates the average of fibre length, cell wall thickness, fibre diameter, lumen and vessel diameter of batai, sesenduk, kedondong and rubberwood. There are marked differences in fibre length between the timber species whereby kedondong having the longest $(2125 \mu \mathrm{m})$, followed by rubberwood $(2028 \mu \mathrm{m})$, sesendok $(1968 \mu \mathrm{m})$ and batai $(1465 \mu \mathrm{m})$. Similar trends were found for fibre wall thickness with kedondong having significantly thicker fibre wall $(6 \mu \mathrm{m})$ than the rest of species. The average fibre diameter was greatest in sesendok $(42 \mu \mathrm{m})$ and lowest in rubberwood $(29 \mu \mathrm{m})$. However,

Table 1 Anatomical characteristics of batai, sesendok, kedondong and rubberwood

\begin{tabular}{lcccccc}
\hline Species & $\begin{array}{c}\text { Density } \\
\left(\mathrm{kg} \mathrm{m}^{-3}\right)\end{array}$ & $\begin{array}{c}\text { Fibre length } \\
(\mu \mathrm{m})\end{array}$ & $\begin{array}{c}\text { Fibre wall thickness } \\
(\mu \mathrm{m})\end{array}$ & $\begin{array}{c}\text { Fibre diameter } \\
(\mu \mathrm{m})\end{array}$ & $\begin{array}{c}\text { Lumen diameter } \\
(\mu \mathrm{m})\end{array}$ & $\begin{array}{c}\text { Vessel diameter } \\
(\mu \mathrm{m})\end{array}$ \\
\hline Batai & 358 & $1465^{\mathrm{a}}$ & $2.4^{\mathrm{a}}$ & $29.0^{\mathrm{a}}$ & $24.20^{\mathrm{b}}$ & $158.18^{\mathrm{a}}$ \\
& & $(147)$ & $(0.57)$ & $(7.18)$ & $(7.68)$ & $(10.83)$ \\
Sesendok & \multirow{2}{*}{384} & $1968^{\mathrm{b}}$ & $4.4^{\mathrm{b}}$ & $42.0^{\mathrm{c}}$ & $33.46^{\mathrm{c}}$ & $161.14^{\mathrm{a}}$ \\
& & $(186)$ & $(0.86)$ & $(7.71)$ & $(7.26)$ & $(15.48)$ \\
Kedondong & \multirow{2}{*}{731} & $2125^{\mathrm{cd}}$ & $6.0^{\mathrm{c}}$ & $32.3^{\mathrm{b}}$ & $18.53^{\mathrm{a}}$ & $164.68^{\mathrm{a}}$ \\
& & $(234)$ & $(1.53)$ & $(5.47)$ & $(7.04)$ & $(15.52)$ \\
Rubberwood & 593 & $2028^{\mathrm{bc}}$ & $4.5^{\mathrm{b}}$ & $24.2^{\mathrm{a}}$ & $15.20^{\mathrm{a}}$ & $177.09^{\mathrm{b}}$ \\
& & $(67)$ & $(0.82)$ & $(2.27)$ & $(2.81)$ & $(11.08)$ \\
\hline
\end{tabular}

Means followed by the same letter in the same column are not significantly different at $\mathrm{p} \leq 0.05$ according to least significant difference test; values in parentheses are standard deviations 
there was no significant difference in fibre diameter between batai and rubberwood. Both kedondong and rubberwood had significantly smaller lumen diameter while sesendok had the widest lumen diameter $(33.46 \mu \mathrm{m})$. Rubberwood had the greatest vessel diameter $(177.09 \mu \mathrm{m})$ in comparison with the other three wood species.

The anatomical features of batai, sesendok, kedondong and rubberwood are shown in Figures 1-4. Batai (Figure 1) shows that the vessels are arranged in diffuse porous, predominantly solitary and in radial multiples of 2 to 4 . Batai has a vessel diameter of $158.18 \mu \mathrm{m}$. Tyloses and deposits are absent. The rays of batai are usually uniseriate although sometimes present as biseriates. Figure 2 shows the anatomical features of sesendok showing vessels are predominantly present in radial pairs and in multiples of 2 to 7 , each with diameter $161.14 \mu \mathrm{m}$. Briefly, it is moderately large in size, but few in numbers. The tyloses and deposit are distinctly absent. Rays are 1 to 2 seriate. Kedondong demonstrates a different feature (Figure 3). Its vessels are predominantly in radial pairs and in multiples of 2 to 6 whilst rays are uniseriate and partly biseriate. The vessels are moderately numerous and in medium size with diameter $164.68 \mu \mathrm{m}$. Tyloses are present while deposits are absent. Rubberwood on the other hand, contains vessels that are solitary and in radial multiples of 2 to 4 (Figure 4). The rays are multiseriate and the vessels are large with diameter $177.09 \mu \mathrm{m}$ and few in numbers with the present of tyloses.

\section{Wood density}

With the longest fibre length and thickest fibre wall, kedondong also had the highest density followed by rubberwood, sesendok and batai (Table 1). This relationship between density and fibre length and thickness of fibre wall was also reported by Humberto et al. (2016) whereby density of wood depends on cell wall thickness and fiber length.
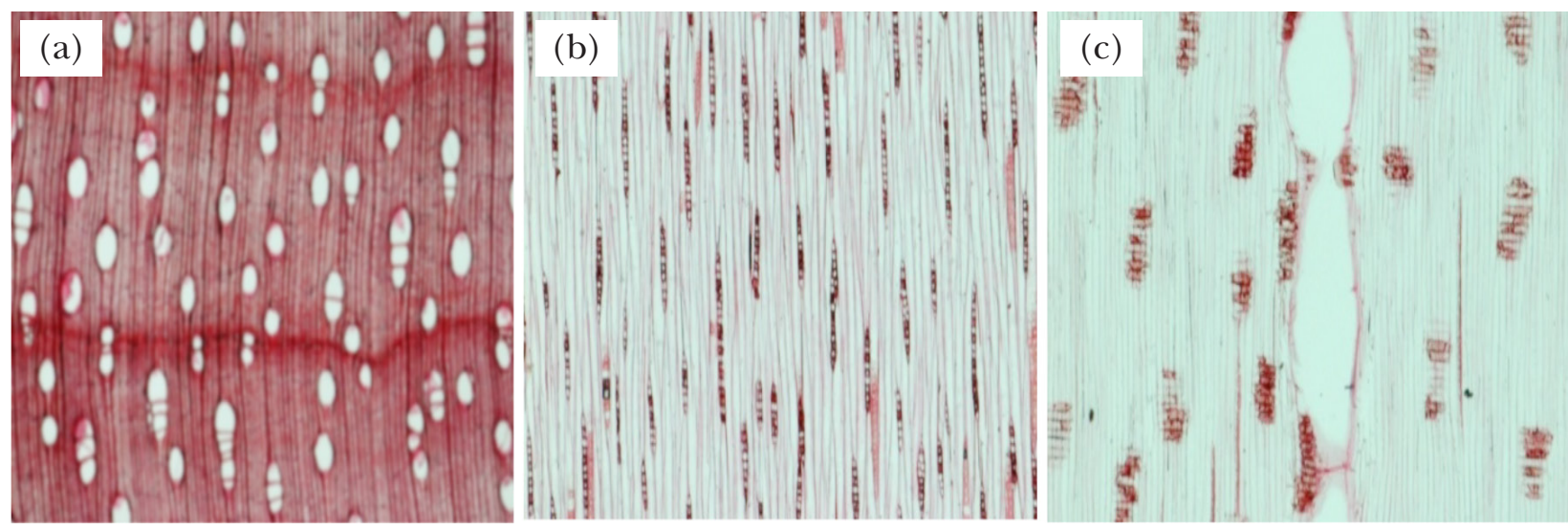

Figure 1 Batai: (a) cross-section, (b) tangential section and (c) radial section (magnification 50×)
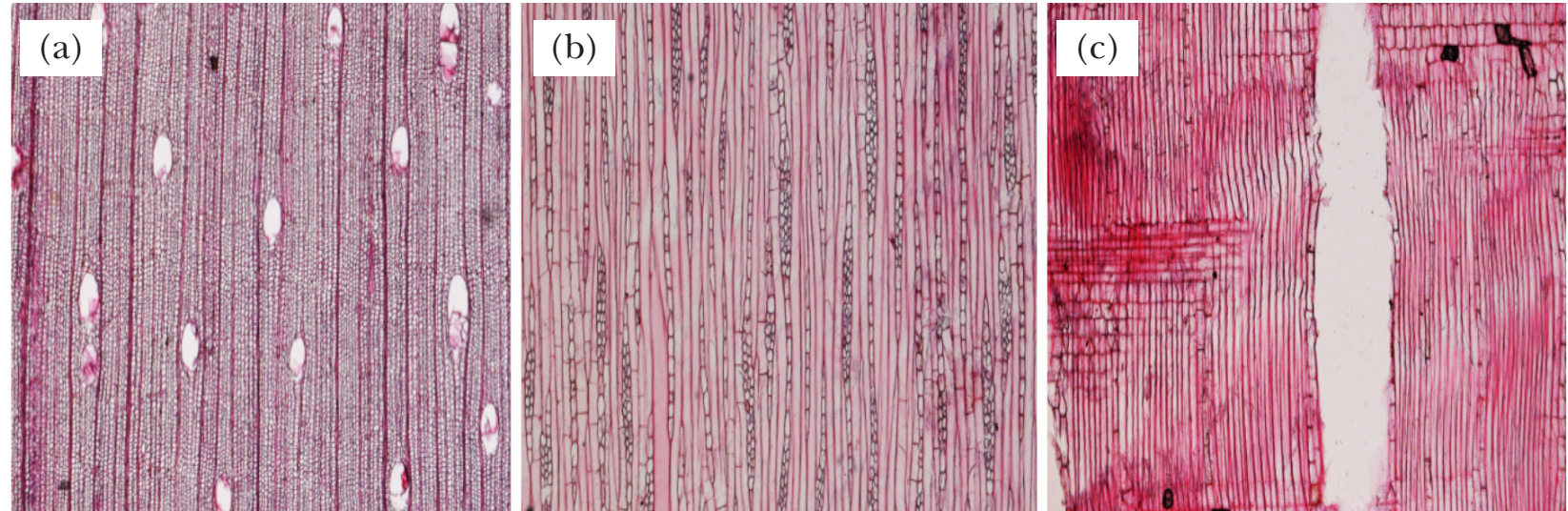

Figure 2 Sesendok: (a) cross-section, (b) tangential section and (c) radial section (magnification 50×) 

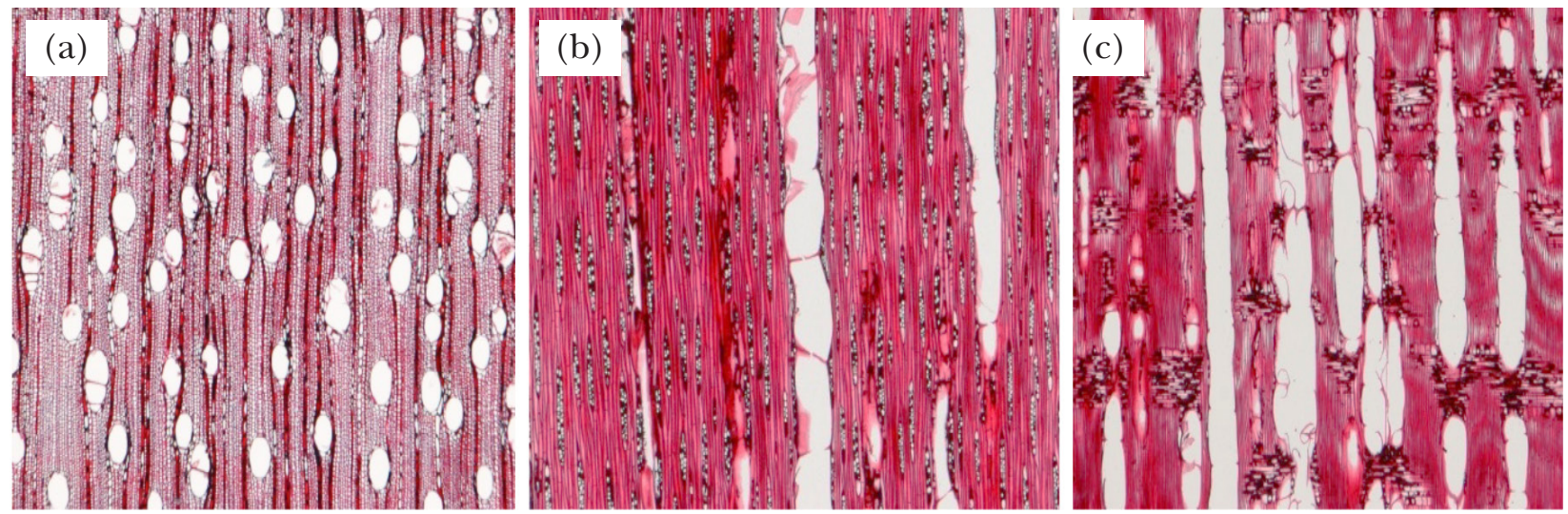

Figure 3 Kedondong: (a) cross-section, (b) tangential section and (c) radial section (magnification 50×)
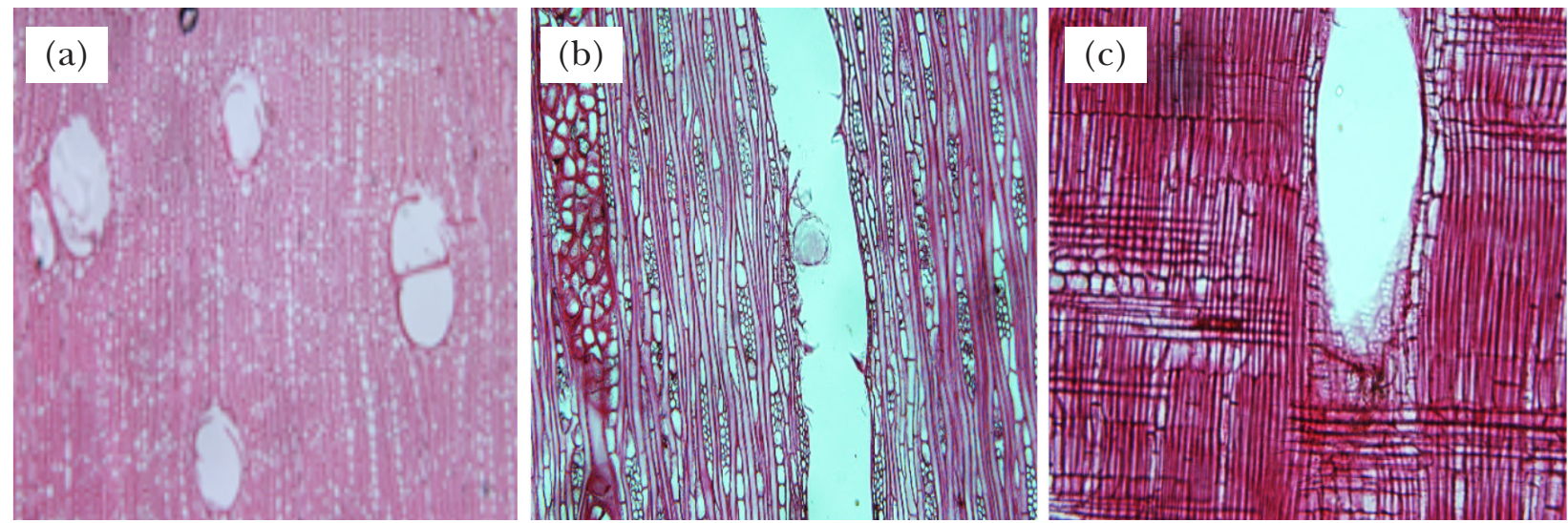

Figure 4 Rubberwood: (a) cross-section, (b) tangential section and (c) radial section (magnification 50×)

Wood with lower density normally have wider lumen diameter (Rafael et al. 2013). In this study, however, fibre and lumen diameters did not significantly affect density. For instance, rubberwood had narrow lumen diameter but had lower density than kedondong that had a wider lumen diameter. This may be attributed to the presence of larger vessel diameter in rubberwood $(177.09 \mu \mathrm{m})$ compared with kedondong (164.68 $\mu \mathrm{m})$. Wood density is defined by the vessel size and number in the wood where larger vessel size and higher vessel number would result in low density (Leal et al. 2011).

\section{Surface roughness}

Surface roughness parameters of wood species are given in Table 2. Kedondong had the smoothest surface with an average roughness value of $4.03(\mu \mathrm{m})$ while batai had roughest surface with an average roughness value of $8.88 \mu \mathrm{m}$ followed by sesendok $(6.61 \mu \mathrm{m})$. Rubberwood and kedondong had similar average roughness values. We thus concluded that surface roughness of tropical hardwood was affected by wood density. According to Hiziroglu et al. (2008) and Amorim et al. (2013) wood density is inversely correlated to the surface roughness. Other plausible factor that may influence surface roughness, particularly for low-density wood such as batai and sesendok is the size of voids that are present in the wood. Wood with large lumen and vessel diameters would usually result in open grain after machining, and this could lead to higher surface roughness.

\section{Contact angle}

Contact angles were significantly different between the timber species axcept for batai and sesendok (Figure 5). Contact angle decreased as a function of time. The contact angles for batai, sesendok, kedondong and rubberwood were $32.25^{\circ}, 36.12^{\circ}, 47.77^{\circ}$ and $42.92^{\circ}$ respectively. The contact angle of batai decreased from $32.25^{\circ}$ to $0^{\circ}$ within $7 \mathrm{~min}$, much faster than the 
Table 2 Surface roughness across the grain of wood

\begin{tabular}{lccc}
\hline Species & $\begin{array}{c}\text { Average roughness } \\
(\mu \mathrm{m})\end{array}$ & $\begin{array}{c}\text { Square root of average } \\
\text { roughness }(\mu \mathrm{m})\end{array}$ & $\begin{array}{c}\text { Mean peak-to-valley height } \\
(\mu \mathrm{m})\end{array}$ \\
\hline Batai & $8.88^{\mathrm{a}}$ & $11.53^{\mathrm{a}}$ & $48.26^{\mathrm{a}}$ \\
Sesendok & $6.61^{\mathrm{b}}$ & $8.63^{\mathrm{a}}$ & $37.75^{\mathrm{b}}$ \\
Kedondong & $4.03^{\mathrm{c}}$ & $5.34^{\mathrm{b}}$ & $25.63^{\mathrm{c}}$ \\
Rubberwood & $4.36^{\mathrm{c}}$ & $5.44^{\mathrm{b}}$ & $23.65^{\mathrm{c}}$ \\
\hline
\end{tabular}

Means followed by the same letter in the same column are not significantly different at $\mathrm{p} \leq 0.05$ )

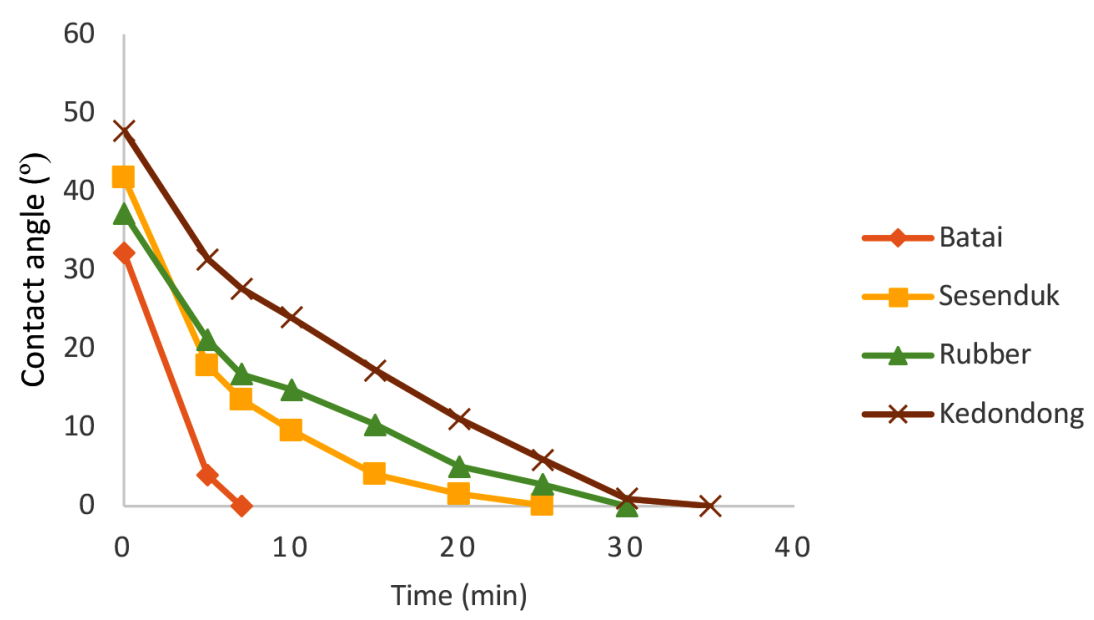

Figure 5 Contact angle changes as a function of time in batai, rubberwood, sesendok and kedondong

rest of the species. Kedondong took $35 \mathrm{~min}$ to completely wet the wood, making it as the least wettable of the four species. Kedondong contained substantial amount of tyloses which prevented water droplet to penetrate its cells. Similarly, rubberwood with relatively smooth surface (as shown by low average roughess value) and the present of tyloses resulted in the second highest contact angle between the samples. Water penetrates slower into smooth surface area than into rough surface and results in higher contact angle and poor surface wettability (Arnold 2010, Agnieszka \& Pawel 2017).

\section{Correlation analysis between wood anatomical} characteristics, density and studied parameters

\section{Density}

Table 3 shows the results of the correlation between anatomical characteristics and density. High correlation was obtained between density and fibre length, fibre diameter and vessel diameter for batai, sesendok and kedondong, while moderate correlation was observed for rubberwood. Fibre length has been reported to show negligible correlation with density (Dean et al. 2002) and this was the observation in this study. In contrast, fibre wall thickness and lumen diameter were the more influential factors on the wood density and similar findings were reported by Qumruzzaman et al. (2012), Kiaei (2011) and Maharani and Andrian (2015).

\section{Surface roughness}

The relationship between anatomical characteristics and surface roughness are shown in Table 4. Fibre length, wall thickness and lumen diameter had strong correlations with surface roughness. Fibre diameter of batai showed moderate correlation $\left(\mathrm{r}^{2}=0.558\right)$ with surface roughness while vessel diameter had poor relation.

\section{Contact angle}

Very high correlations were found between all anatomical characteristics and contact angles, except for vessel diameter (Table 5). The highest 
Table 3 Regression coefficient for the relationships between wood anatomical and density of individual species

\begin{tabular}{lcccc}
\hline Correlated parameters & \multicolumn{3}{c}{ Regression coefficient } \\
\cline { 2 - 4 } & Batai & Sesendok & Kedondong & Rubberwood \\
\hline Fibre length $\times$ density & 0.669 & 0.793 & 0.969 & 0.340 \\
Fibre diameter $\times$ density & 0.841 & 0.680 & 0.786 & 0.313 \\
Fibre wall thickness $\times$ density & 0.814 & 0.866 & 0.936 & 0.672 \\
Lumen diameter $\times$ density & 0.727 & 0.809 & 0.882 & 0.592 \\
Vessel diameter $\times$ density & 0.401 & 0.722 & 0.491 & 0.852 \\
\hline
\end{tabular}

Table 4 Regression coefficient for relationship between wood anatomical and surface roughness of individual species

\begin{tabular}{lcccc}
\hline Correlated parameters & \multicolumn{3}{c}{ Regression coefficient } \\
\cline { 2 - 4 } & Batai & Sesendok & Kedondong & Rubberwood \\
\hline Fibre length $\times$ surface roughness & 0.752 & 0.915 & 0.985 & 0.757 \\
Fibre diameter $\times$ surface roughness & 0.558 & 0.784 & 0.725 & 0.740 \\
Fibre wall thickness $\times$ surface roughness & 0.768 & 0.861 & 0.892 & 0.927 \\
Lumen diameter $\times$ surface roughness & 0.797 & 0.910 & 0.860 & 0.840 \\
Vessel diameter $\times$ surface roughness & 0.19 & 0.722 & 0.132 & 0.228 \\
\hline
\end{tabular}

Table 5 Regression coefficient for the relationship between wood anatomical and contact angle of individual species

\begin{tabular}{lcccc}
\hline Correlated parameters & \multicolumn{3}{c}{ Regression coefficient } \\
\cline { 2 - 4 } & Batai & Sesendok & Kedondong & Rubberwood \\
\hline Fibre length $\times$ contact angle & 0.778 & 0.888 & 0.975 & 0.920 \\
Fibre diameter $\times$ contact angle & 0.790 & 0.922 & 0.852 & 0.647 \\
Fibre wall thickness $\times$ contact angle & 0.867 & 0.749 & 0.860 & 0.794 \\
Lumen diameter $\times$ contact angle & 0.849 & 0.830 & 0.789 & 0.941 \\
Vessel diameter $\times$ contact angle & 0.006 & 0.581 & 0.021 & 0.321 \\
\hline
\end{tabular}

correlation was obtained between fibre length and contact angle. Differences in wettability are attributed to anatomical and chemical properties of wood species (Buyuksari et al. 2011, Shupe et al. 2001). Different diameters of wood cells can influence the penetration behaviour of liquid into the wood surfaces (Scheikl \& Dunky 1998).

\section{Factors influencing surface wettability}

The overall correlations between species and contact angle were analysed and summarised in Table 6 to ascertain the property that had the highest influence on surface wettability. Fibre wall thickness $\left(r^{2}=0.803\right)$, surface roughness $\left(r^{2}=0.800\right)$ and density $\left(r^{2}=0.744\right)$ were the most influential factors that affected surface wettability of wood. Surface wettability is highly dependent on density and surface roughness of wood (Nadir et al. 2010, Rolleri et al. 2016, Agnieszka et al. (2018). Lumen diameter, fibre length, fibre and vessel diameter did not exert any significa influence of surface wettability of wood.

\section{CONCLUSIONS}

Contact angle had strong relationship between anatomical characteristics and surface wettability. Vessel diameter of rubberwood was found to 
Table 6 Summary of regression coefficient $\left(\mathrm{r}^{2}\right)$ of factors influencing surface wettability of overall wood species

\begin{tabular}{lc}
\hline Correlated parameters & $\mathrm{r}^{2}$ of overall species \\
\hline Fibre length $\times$ contact angle & 0.203 \\
Fibre diameter $\times$ contact angle & 0.110 \\
Fibre wall thickness $\times$ contact angle & 0.803 \\
Lumen diameter $\times$ contact angle & 0.352 \\
Vessel diameter $\times$ contact angle & 0.037 \\
Density $\times$ contact angle & 0.744 \\
Surface roughness $\times$ contact angle & 0.800 \\
\hline
\end{tabular}

behave very differently than the other three species while batai and sesendok were quite similar. The wettability of batai was highly influenced by fibre wall thickness and lumen diameter while sesendok was influenced by fibre diameter, fibre length and lumen diameter. For kedondong, wettability was influenced by the fibre diameter, fibre length and fibre wall thickness. Fibre length and lumen diameter affected the wettability of rubberwood significantly. Correlation analysis based on all species indicated that the density and surface roughness were highly influenced by fibre wall and cell wall thickness, and that contact angle was governed by fibre length, fibre diameter, fibre wall thickness and lumen diameter. Surface wettability of the wood was mainly influenced by fibre wall thickness and surface roughness.

\section{ACKNOWLEDGEMENT}

The authors wish to thank the Higher Institution Centre of Excellence for financial support.

\section{REFERENCES}

Agnieszka J, Zbiec M, Kozakiewicz P, Koczan G, Oleńska S \& BeER P. 2018. The wettability and surface free energy of sawn, sliced and sanded European oak wood 20: 443-454. doi: $10.4067 / \mathrm{S} 0718$ 221X2018005031401.

Agnieszka L \& Pawel K. 2017. Surface wettability of wood species from tropical and temperate zones by polar and dispersive liquids. Drvna industrija 68: 299-306.

Amorim MRS, Ribeiro PG, Martins SA, Del Menezzi CHS, De SouzA MR. 2013. Surface wettability and roughness of 11 Amazonian tropical hardwoods. Floresta e Ambiente 20: 99-109. http://dx.doi.org/10.4322/ floram.2012.069.

ARNold M. 2010. Planing and sanding of wood surfaces-effect on surface properties and coating performance. Surface Coating International 94: 170-176.
ASTM. 2002. ASTM D2395-02. Standard Test Methods for Specific Gravity of Wood and Wood-Based Materials. ASTM International, West Conshohocken.

Bao M, Huang X, Zhang Y, Yu W \& Yu Y. 2016. Effect of density on the hygroscopicity and surface characteristics of hybrid poplar compreg. Journal of Wood Science 62: 441-451. https://doi.org/10.1007/ s10086-016-1573-4

Buyuksari U, Akbulut T, Guler C \& As N. 2011. Wettability and surface roughness of natural and plantationgrown narrow-leaved (Fraxinus angustifolia Vahl.) wood. BioResources 6: 4721-4730.

CHENG E \& Sun X. 2012. Effects of wood-surface roughness, adhesive viscosity and processing pressure on adhesion strength of protein adhesive. Journal of Adhesion Science and Technology 20: 997-1017. https:/ / doi.org/10.1163/156856106777657779

Dean SD, Ryan S, Constance AH \& Barbara LG. 2002. Wood density and fiber length in young populus stems: relation to clone, age, growth rate and pruning. Wood and Fiber Science 4: 529-539.

Hiziroglu S, Anwar UMK, Hamdan H \& Paridah MT. 2008. Evaluation of surface quality of some Malaysian species as function of outdoor exposure. Journal of Materials Processing Technology I99: 156-162.

Humberto GR, Ratikanta M, Aruna K \& Sarkar MC. 2016. Variability in wood density and wood fibre characterization of woody species and their possible utility in Northeastern Mexico. American Journal of Plant Sciences 7: 1139-1150. doi: 10.4236/ ajps.2016.77109.

ISO. 1997. ISO 4287: Geometrical Product Specifications (GPS). Surface Texture: Profile Method-Terms, Definitions and Surface Texture Parameters. International Organization for Standardization, Geneva.

Kiaei M. 2011. Anatomical, physical, and mechanical properties of eldar pine (Pinus eldarica Medw.) grown in the Kelardasht region. Turkish Journal of Agriculture and Forestry 35: 31-42. doi: 10.3906/tar-1001-552.

Leal S, Sousa VB, Knapic S, Louzada JL \& Pereira H. 2011. Vessel size and number are contributors to define wood density in cork oak. European Journal of Forest Research 130:1023-1029.

Maharani R \& Andrian F. 2015. Correlation between wood density and fiber length with essential macronutrients on base of stem of Shorea leprosula and Shorea parvifolia. Pp 625-629 in The $3^{\text {rd }}$ International 
Conference on Biological Science 2013 (ICBS-2013). 17 September 2013, Faculty of Biology, Universitas Gadjah Mada, Yogyakarta.

Nadir A, Candan Z, Turgay A \& Ozgur DB. 2010. Effect of sanding on surface properties of medium density fiberboard. Drvna Industrija 61: 175-181.

Nordahlia AS. 2009. Wood quality of ten-year-old sentang (Azadirochla excelsa) grown from seedlings and rooted cuttings. MSc thesis, Universiti Putra Malaysia, Serdang.

Qumruzzaman CMD, Ishiguri F, Hiraiwa T et al. 2012. Variation in anatomical properties and correlations with wood density and compressive strength in Casuarina equisetifolia growing in Bangladesh. Australian Forestry 75: 95-99. https://doi.org/10.10 80/00049158.2012.10676390

Rafael CA, Berenice AD, Marçal JRP \& Suzana FF. 2013. Relationship between density and anatomical structure of different species of eucalyptus and identification of preservatives. Material Research 6 : $1428-1438$.
Rolleri A, Burgos-Olavarria F \& Aguilera A. 2016. Surface roughness and wettability variation: the effect of cutting distance during milling of pinus radiata wood. Drvna industrija 67: 223-228.

Scheikl M \& Dunky M. 1998. Measurement of dynamic and static contact angles on wood for the determination of its surface tension and penetration of liquids into the wood surface. Holzforschung 52: 89-94.

SHI SQ \& GARDNER DJ. 2001. Dynamic adhesive wettability of wood. Wood and Fiber Science 33: 58 $\div 68$.

Shupe TF, Hse C \& WANG WH. 2001. An investigation of selected factors that influence hardwood wettability. Holzforschung 55: 541-548.

Wheeler EA, BaAs P \& Gasson PE. 1989. IAWA list of microsopie features for hardwood identification. IAWA Journal/International Association of Wood Anatomists 10: 219-332.

Wiedenhoeft AC. 2013. Structure and function of wood. Pp 9-32 in Rowell RM (ed) Handbook of Wood Chemistry and Wood Composites. CRC Press, Taylor \& Francis Group, Boca Raton. 